\title{
Ethics Precedes Religious Beliefs: The Basis of Solidarity
}

\author{
PETER CHONG-BENG GAN \\ School of Humanities, Universiti Sains Malaysia, \\ 11800 USM Pulau Pinang, Malaysia \\ petergan@usm.my
}

Published online: 15 October 2016

To cite this article: Gan, P. C-B. 2016. Ethics precedes religious beliefs: The basis of solidarity. KEMANUSIAAN the Asian Journal of Humanities 23(2): 51-69, http://dx.doi.org/10.21315/ kajh2016.23.2.4

To link to this article: http://dx.doi.org/10.21315/kajh2016.23.2.4

\begin{abstract}
In this paper, I attempt to engage with the evidentialist principle of William Clifford in conjunction with the normative that the doctrinal and practical correlates of religious beliefs ought not to endorse any serious moral violations. This in turn facilitates the articulation of a structure for the basis of solidarity amongst people of different faiths. With the help of Kant's reflections on the concept of faith and on religion, I argue that ethics ought to have priority over religious beliefs, and this is essential in establishing a foundation for fostering an integrative existence amongst members of a multi-religious polity.
\end{abstract}

Keywords and phrases: ethics of belief, religion, ethics, solidarity, evidentialist

The main ideas that I intend to engage with in this paper are "the ethics of belief," "beliefs with ethics," and "solidarity." These three ideas are directed at supporting the central thesis that ethics precedes religious beliefs, especially with respect to the authoritative force of epistemic and moral norms. I am not saying that ethics is logically prior to religious beliefs, whereby it is logically impossible to have religious beliefs without ethics. Rather, my contention is that while the considerations of ethics, including the moral responsibility to hold true beliefs, may override religious beliefs, the reverse is not the case. Also, from this central thesis a theoretical basis for inter-religious solidarity can be formed. In section one (after this introduction), I shall first resurrect the debate revolving around the possibility of our beliefs coming under moral scrutiny. The chief participants in this debate are Blaise Pascal, William Clifford, and William James. My contention is that religious beliefs are a contributing factor to our actions that can be judged as morally right or wrong, and hence, cannot be exempted from a moral evaluation predicated on the evidential sufficiency, or lack thereof, in support of such beliefs. I plan to work out a particular rendition of Clifford's 
evidentialist principle to help strengthen its applicatory value. Section two constitutes an attempt to bring some relevant discussions to conclude that religious beliefs ought not to violate the rational precepts of ethics, and that ethics functions as the ultimate authoritative force cautioning against any excesses of faith-sourced activities that are morally perverse. This conclusion will also serve as a presupposition for interpreting Clifford's principle. Additionally, I maintain that revelation should not supersede the ethical imperative. The last section of this paper delineates the role that the religious discourse, a discourse that is principally dialectical in form, and a foundation of religion as firmly entrenched in ethics, plays in facilitating social cohesion in plural societies. Immanuel Kant will join the three thinkers mentioned above to form the main line-up of writers whom I shall rely upon for putting forth my ideas and arguments in this paper.

\section{The Ethics of Belief}

William Clifford's essay in response to Blaise Pascal's suggestion that it is sounder to bet on faith than on unbelief is titled "The Ethics of Belief" (Clifford 1877, 177-211). Pascal tells us that even if we can never rationally support either the existence or non-existence of God, it would be prudent to wager on the belief that there is a God for we have nothing to lose but everything to gain (Pascal 1910, 1669, section III: 233, 83-87). Clifford, on the other hand, views any holding of beliefs on insufficient evidence to be immoral. His standpoint is embedded in the following excerpt from "The ethics of belief":

[I]t is wrong always, everywhere, and for anyone, to believe anything upon insufficient evidence. If a man, holding a belief which he was taught in childhood or persuaded of afterwards, keeps down and pushes away any doubts which arise about it in his mind, purposely avoids the reading of books and the company of men that call in question or discuss it, and regards as impious those questions which cannot easily be asked without disturbing it - the life of that man is one long sin against mankind (Clifford 1877, 186-187).

Clifford assumes an unrelenting moral position in his interpretation of the evidentialist principle. In "evidentialism," an epistemological principle, the only epistemic justification for a person $X$ believing a proposition $p$ at time $t$ is the evidence $X$ has at $t$ for supporting $p$ being true (Mittag n.d.). There is an extensive and valuable debate revolving around this definition of evidentialism, but due to space constraints, I cannot fully engage with it in this paper. It appears that a strong case exists for evidentialism even though the content of this case may be unraveled somewhat differently by different philosophers. ${ }^{1}$ I submit that beliefs 
are governed by the norm orientated towards objective truths. I may, however, have beliefs directed to subjective truths, as for instance, I believe that I find spicy food terrible. Nevertheless, the norm orientated to objective truths still applies in this instance because I also realise that it is objectively true that my aversion is purely subjective. However, when considering religious beliefs, the issue of the sufficiency of evidence has to be examined and adjusted to accommodate this type of beliefs. Although evidentialism will not be comprehensively discussed, its version as espoused by Clifford's "ethics of belief" forms the basis of this paper's analysis. Clifford's ethical perspective on the evidentialist principle will be examined in tandem with the epistemological aspect of this principle.

A careful examination of Clifford's statements above indicates that the moral obligation leagued with belief has more to do with the procedures that relate to the belief - voluntary efforts undertaken to gather and assess all information relevant to the belief, and the willingness to consider countervailing evidence. It is these elements that determine the moral value of our beliefs. Elsewhere, Clifford argues that even if our beliefs, formed without sufficient evidence, were later vindicated through confirming events, this later vindication does not absolve the subject of the earlier immorality of holding the said beliefs (Clifford 1877, 178). For example, without responsibly collecting sufficient data relevant to a decision to undertake a major and high-risk business venture I decide in favour of that venture. When later, profits begin to pour in as a result of the success of this business I assume (wrongly) that I was not morally culpable for my reckless violation of the evidentialist principle. Conversely, despite my careful consideration of all relevant information that contributed to my belief in the prospective success of a business venture, the outcome in reality later proved to be just the opposite, I did indeed fulfil my obligation of endeavouring to secure a belief backed by adequate evidence and maintaining an open mind towards any emerging countervailing evidence.

Now, surely, one might protest saying that it is impossible for a person to be fully furnished with all necessary evidence to warrant embracing a belief that satisfies the evidentialist principle. If this were the case then the only sort of beliefs that we are justified in holding would be trivial ones or beliefs that have little consequence to us; for instance, I believe I am presently seated at my desk and typing out an article on my computer. For, if strict adherence to Clifford's maxim is to be expected, then I am certain that many of my students would not be able to make up their minds on the best major to pursue in their university education. If I had to make sure that I gather enough evidence to believe that so and so is the correct person to be my spouse, I probably would take forever to decide whether I should marry that so and so person! 
It may also be objected by saying that beliefs, which lie in the domain of a person's internal thoughts and attitudes, are not liable to moral appraisals because only external actions have moral significance. Virtue ethicists such as Aristotle would disagree that internal dispositions are devoid of moral value. Aristotle's notion of moral virtues as internal dispositions to behave morally, which are cultivated through voluntary, habitual actions, can be used to support the idea that beliefs adopted by a person are liable to moral appraisals (Aristotle 1976, 4th cent. BCE, 1103 a14-b25 and 1144 a3-24, 91-92 and 222). Correspondingly, a person can cultivate a habit of discerningly evaluating relevant data to form sufficiently supported beliefs, and these beliefs have moral worth because they also have an impact upon their holder's future actions.

The evidentialist principle cannot be easily dismissed. Imagine if you were diagnosed with a serious illness that is treatable, but necessitates a risky surgery. Now, imagine that your primary doctor who will also perform the surgery, without careful consideration of your particular medical condition and without measuring the cost-benefit situation of the surgery, very cavalierly believes that you should undergo the prescribed risky treatment. Should you not regard this belief of his to be resting on insufficient evidence, and that if you were to submit to his counsel you would be staking your life on this same unreliable belief? Clifford's ethics of belief, I am sure you would agree, bears heavily on this situation. In this regard too, beliefs, though internal, conduce to morally significant consequences, and hence, are themselves morally assessable.

Let me attempt to connect the ethics of belief to religion. Someone might comment that when comparing a major surgery with the considerations of fundamental orientations of religion, the former has a lot at stake while matters of religion are quite dispensable. The contention here is that while the ethics of belief applies to the former, religious beliefs are exempted from the moral obligation to garner sufficient evidence because such beliefs have minimal moral consequence either to self or to society. But, this argument lacks force. Commitment to a religious faith makes serious demands upon us and far from it having minimal moral consequence, for a number of people, their respective religious beliefs permeate practically their whole lives. William James is convinced that religious propositions pertaining to questions regarding the existence of God, afterlife, meaningful human existence, and the issue of salvation embody options that are living, momentous, and unavoidable (James 1897/1912, 3-6). These options matter to us, they have a significant impact on us, and not to choose to believe the propositions is to choose against them. Moreover, apart from the fact that ethics figure prominently in the teachings of major living religions (see Singer 1991/1993, 43ff.), the ultimate concerns that preoccupy these religions serve as motivating forces for religious believers' moral actions. In essence, one cannot exempt religious beliefs from compliance with the 
evidentialist principle on the misperceived grounds that they have little moral consequence.

However, can religious beliefs be spared the moral obligation of evidentialism for a different reason - they are not susceptible of proof via sufficient evidence (as we ordinarily conceive of what counts as evidence: can be reasonably verified; or able to appeal to some universal consensus; or having some foundation in facts)? Based on the fact that I presently have absolutely negligible knowledge of Pascal programming, I have sufficient evidence to make me believe that if I were to sit for an exam on this subject this very evening, I would surely fail it. But, can anyone shore up adequate proof that there is life after death or that there is a supreme being who is sincerely concerned about our welfare here on earth? It appears that religious beliefs can never be adequately supported by evidence. Perhaps, Immanuel Kant can help throw some light on the concept of faith or religious belief.

To understand better Kant's general concept of faith, we have to examine how he distinguishes between opinion, knowledge, and faith (Kant 1787/1991, 465469). ${ }^{2}$ Putting it briefly, while I may have an opinion of, say, the beautiful vistas of Patagonia in South America (based on its description relayed to me by someone else), and knowledge of myself feeling anxious at this moment, or "1 + $1=2$ ", faith relates to judgments based on speculative reason. Faith cannot make a claim to knowledge, but Kant thinks that its subjective conviction goes beyond opinion. It can be said that once certainty sets in, faith disappears. In ordinary language, we say "I have faith that there is a God" and not "I have faith that $1+1$ $=2 . "$ Unlike opinion (that has the possibility of either arriving at knowledge, or being refuted), faith is beyond refutation and confirmation by knowledge. An important type of faith is what Kant calls doctrinal faith as having belief in the existence of God that guarantees the ultimate coincidence between virtue and happiness, and thereby providing the impetus to lead a moral life (Kant 1787/1991, 468-469). Doctrinal faith cannot venture to make judgments speculating the nature of its object of belief. Instead, since it has little theoretical content in terms of true knowledge, its relevance is in reference to its capacity to evoke moral action. Judgments that are said to be true in the frame of faith are held to be such only in terms of their necessity in realising the objectives of certain actions. Doctrines of faith are perpetually open to interrogation at many levels: the authenticity of the original revelation and the historical dissemination of that message, and even the existence of the revered ultimate principle.

Given the epistemic nature of doctrinal faith, when comparing between rational ethics and religious beliefs, it is ethics that is firmly rooted in moral reason that should be accorded the priority in governing the way we live. Moral reason 
entails the submission of deliberations on moral issues and theories to the rigours of inductive and deductive reasoning and formulation of sound judgments and inferences; and this confers a relatively higher degree of epistemic security upon ethics. However, it does not mean that religious devotion has absolutely no role to play in our lives. Kant considers religious devotion as having the potential to supplement moral life. In fact, for Kant, the postulates of God's existence and the immortality of the soul underwrite morality (Kant 1817/1978, 110-111). It would seem "irrational" if at the end of all our sacrifices for being moral, there is no proportioning of happiness to virtue. The existence of God and the immortality of the soul are conditions of possibility for such a just culmination (more on this later). It appears that Kant shares with James a similar position on religious beliefs - their value is more pragmatic than epistemic. To roughly illustrate the difference between the two: one may know the limits of knowledge (epistemic) about the existence of God, but one may still live and behave as if God exists (pragmatic) because of the usefulness of such a way of living and behaving.

Regarding the above point on religious beliefs' exemption from the evidentialist principle because such beliefs intrinsically lack evidence, one is pushed to ask: is it really the case that religious beliefs categorically cannot be supported by sufficient evidence? James argues that it is ridiculous to abstain from adopting a religious belief until sufficient evidence is in one's hand because, for James, the value of religious faith resides in its usefulness to the believer (James 1897/1912, 10-11). Many have attested to the consolation and strength that religious beliefs bestow upon them (see Schopenhauer 1851/1897, 98). ${ }^{3}$ But, should we not exercise caution here, for, holding beliefs because it is useful to do so is distinct from the truth or falsity of the content of these beliefs? The truth of the content of our faith is not positively correlated to the magnitude and usefulness of our faith. No matter how much we have faith in God's existence-assuming that the concept "God" is not entirely equated with our subjectively enacted experience of a subjectively conceived notion of God - this does not increase the probability that God really exists. Such an existence is said to be either objectively true or objectively false. The same applies to beliefs about the afterlife. Even if a person finds life manageable and fulfilling by believing that there is a loving God and eternal happiness in the next life, these belief statements are not rendered true simply by believing in them. Note that it is an entirely different matter in a situation in which a less than healthy individual actually attains perfect health largely due to believing that he or she is already healthy. In this type of situation, believing $x$ helps to make $x$ true.

I should be careful when justifying faith in religious doctrines by appealing to the consolation and other positive feelings obtainable from having such faith. Good feelings alone cannot be used as a barometer to measure the goodness of a course of action. Unscrupulous individuals who violate serious moral precepts without a 
flinch of guilt have felt good about themselves, but this positive feeling does not render their actions morally right.

I would conclude that there is no persuasive reason to exclude religious beliefs from Clifford's evidentialist principle. If we are beings committed to truth and honesty, then we have to take seriously the evidence of our beliefs. The crucial question then is: what constitutes sufficient evidence? For sure, there is a spectrum of sorts of evidence required for different sorts of propositions. Propositions that are amenable to empirical verification ought to be subjected to it. If I claim to see a line of people sitting in front of me I should at least be able to approach them and touch them to make sure that I am not hallucinating, or that I can check with the person next to me to corroborate what I see. On the other hand, metaphysical claims of religious doctrines belong to a different category. Virtually all of their claims are not directly verifiable by our physical senses. They are, however, somewhat amenable to the types of epistemic justification that pertain to inferential reasoning from indirectly related empirical data. There are individuals such as mystics who claim to have a direct experience of God. Notwithstanding the structural differences between experiencing God and experiencing a physical object, as well as a different manner in which some consensus of this God-experience can be reached amongst experiencing subjects, one cannot deny that these special experiences can legitimately contribute to forming religious beliefs. ${ }^{4}$ Nevertheless, it can still be maintained that religious beliefs have a lesser capacity for objective verification as compared with other types of belief. In view of the ethics of belief's basis in the procedure and attitude connected to holding beliefs, and the obscurity of determining what fulfils the evidential sufficiency requirement for religious beliefs, as long as one maintains a critical posture towards one's held religious beliefs, this evidential principle is adhered to. In addition, Clifford's principle functions as a cautionary procedure, by which religious beliefs that possess a high probability of expressing themselves in actions contravening moral reason are liable to be judged as insufficiently backed by evidence and accordingly, in violation of the said principle.

It is worth noting that even if one were to believe a proposition simply because it is useful to do so there is in here an implicit belief in an assumed objective truth in the pragmatic justification for some beliefs. In other words, a truth-oriented epistemic justification for beliefs underpins the pragmatic justification. In the presence of clear evidence that contravenes a belief held on pragmatic grounds, the subject will be compelled to assent to the contrary belief supported by evidence. As Richard Foley illustrates: even though it makes pragmatic sense to believe that the earth is flat if someone promises me a million dollars to do so, it would be virtually impossible for me to sincerely assent to such a belief, simply because existing evidence convinces me otherwise (as mentioned in Shah 2006, 
482). Furthermore, given the nature of religious beliefs as outlined above, an awareness of the lower degree of certainty such beliefs possess as compared with more certain items of knowledge, in itself constitutes an accompanying belief, which reflects the truth-orientating norm that compellingly governs our belief formation. To a degree, a religious belief is analogous to a hypothesis (offering a yet-to-be proven explanation) for a phenomenon. They are both accompanied by a belief in the tentativeness of their truth-claims. In essence, believing on account of evidence is foundational, and it has priority over believing for practical purposes. Incidentally, I should mention that the required sufficiency of evidence for a belief is also a function of the moral consequence of that belief. In my earlier example on the irresponsible surgeon, it seems obvious that his violation of Clifford's principle is more serious as compared with, for instance, my flippant belief that my favourite television programme comes on at 4:00 p.m. tomorrow. On account of the greater moral consequence of the involved belief in the former case, a much greater requirement for sufficiency of evidence is expected to fulfil the evidentialist criteria.

When it comes to beliefs produced by revelation there is always the problematic issue of verifying the authenticity of a recipient's revelation. Moreover, appealing to historical tradition as a means to assess the authenticity of a revelation does not really help. A number of revered originators of major religions who are wellsanctioned by their respective traditions have pronounced distinct creedal statements of their own, purportedly based on revelation. The problem though is that some of the revealed truths of different religions by these well-respected and creditable individuals are quite inconsistent, one with the other. For example, the doctrine of the serial transmigration of the soul may be incompatible with the doctrine of a singular entrance into purgatory, heaven, or hell upon death. While for some religions the mystery of divine incarnation constitutes a core faith tenet, for others, the very idea of God becoming human is abhorrent. Therefore, the appeal to revelation as evidence for doctrinal beliefs is fraught with problems. It may be pointed out that reason has its limitations and problems as well, but I would contend that the limitations within reason are relatively less than that assailing revelation. Also, controversial issues in ethics can be debated upon by appealing to rational justifications. A dispute between contending claims of revealed truths would be invalidly resolved solely by appealing to one revelation as supposedly more "authentic" than the others, and outside of any discussion founded on reason. Rather, disputing parties have to resort to rationally persuasive arguments. Unless a piece of revelation is capable of appealing to some consensus of universal reason, it cannot command the same degree of assent from a population consisting of people from diverse belief systems, as a rationally supported moral precept can. 
A key premise of this paper's thesis is that moral objectivism-which states that there exist moral judgments that are objectively true or false, independently of the appraisals of individuals or societies - reflects the true setting of the realm of moral values. ${ }^{5}$ Deliberations on moral issues can rely upon established systems of normative ethics such as utilitarianism, deontology, and virtue ethics, which possess rationally sound and coherent internal structures. A version of divine command theory of ethics in which an action or state of affairs is deemed moral solely because it is plainly interpreted as being the will of God should not form the basis of moral deliberations. Undoubtedly, the evidentialist principle anchors beliefs upon truths, regardless of whether these truths are religious or moral. However, religious beliefs are comparatively more vulnerable to the problems of verification (as outlined above) than rational ethics are. Since moral beliefs founded on reason and objectivism are less problematic than religious beliefs when it comes to verification, ethics then should guide us in ensuring that we do not hold false religious beliefs.

If the definition of the term "evidence" is given enough amplitude to accommodate different forms and different degrees of justification, then it would be possible for religious beliefs to have evidential validation. Religion should not be perceived as an institution sullied by superstition and irrationality. For religion to regain whatever credibility it may have lost in this contemporary era, it has to be rooted in reason, especially moral reason. Intriguingly, even partisans of extremist and fundamentalist religious sects sometimes feel the need to present ethical justifications (although misguided ones) in support of their extreme standpoints and measures (Atran 2006, 136-137). It appears that the moral imperative is very much part and parcel of our human condition.

In sum, believing in a dogma of faith, and at the same time, believing in the tentativeness and the limited epistemic security of this dogma, satisfy Clifford's evidentialist principle. However, Clifford's principle is absolute in its moral stand - "It is wrong always to..." This absolute stand itself cannot be defended by sufficient evidence. I reject the absoluteness of this principle, and suggest that ethics serve as a regulatory measure whereby while we can never be certain that it is always wrong to hold beliefs without sufficient evidence, we can be certain that it is wrong to hold religious beliefs that are ethically indefensible.

\section{Beliefs with Ethics}

Believers do point to the moral good, to oneself and to others, that issue from believing in articles of faith. Basically, the point put forward is that religion makes one a better person and is responsible for the development of a caring and virtuous world (Putnam and Campbell 2010, 476). Indeed, religion has been the 
initiating and sustaining force in cultivating a moral society, but lest we forget, quite a number of the most heinous crimes against humanity were committed in the name of religion. Incidentally, many non-believers and atheists consider it repugnant when believers assume that without religion, atheists are predisposed to a morally dissolute life and are also constantly in despair. According to atheists, you need not have a religious faith in order to be endowed with a fulfilling, virtuous, and happy life (Myers 2013, 137ff). Many atheists are in fact committed contributors to human flourishing (Kurtz and Craig 2009, 26-27). Interestingly, it is worth asking whether there is sufficient evidence to maintain the belief that those with weakly supported religious beliefs are indeed better off, in all aspects of human existence, than those, say, agnostics, who perhaps, have a relatively stronger evidential support for their stand. ${ }^{6}$ Is there empirical evidence showing that, as Pascal and James suggest, one is better off having a religious belief than not having one?

Let me clarify a couple of things. On account of their profound religious convictions, there are people who have positively transformed their lives and the lives of many others, selflessly made sacrifices, and contributed tremendously to the service of humanity. Does this mean that their morally virtuous deeds all rest on religious beliefs that, by the nature of such beliefs, lack sufficient evidential support, and thereby are unethical by Clifford's evidentialist standards? No. Firstly, as discussed, religious beliefs are amenable to evidential support, even by Clifford's criteria. And, secondly, religious beliefs not tainted by breaches of ethics, are consistent with this paper's thesis. The thesis "ethics precedes religious beliefs" implies that moral virtues may originate from religious as well as nonreligious (or atheistic) convictions, but religious beliefs leading to moral evil can never have evidential support.

I do not think that a belief in God is a necessary condition for an ethical life. The standard of what is morally good or bad is independent of God's command. One can raise the question as to why God considers a particular action to be moral in order to probe towards a justification beyond simply a capricious decision of God. Moreover, the theorem that ethics requires a foundation in God in order to preserve its rationality as well as serve as impetus for moral action (as advanced by Kant), is controvertible. ${ }^{7}$ Philosophical naturalism and humanistic secularism can just as well support the necessity of ethics for the benefit of humanity and the world without positing a supernatural being that is supposed to provide a foundation for ethics. For the humanist, one has a moral obligation to improve oneself and the world in this temporal realm, without presupposing that eternal justice and happiness will always be granted by a supreme being (Kurtz 2001, 145). Propositions on moral matters, which are assumed to be divinely ordained, have to be justified by moral reason. 
There is, however, at least one writer who argues that God, as the originator of ethics, transcends moral reason. This transcendence is represented in the biblical narrative of Abraham's obedience to God's shockingly immoral command to sacrifice Abraham's innocent son, Isaac (Genesis 22, 1-19). ${ }^{8}$ Contrary to Kant's subordination of religious faith to ethics, Søren Kierkegaard's principal assertion in his Fear and Trembling is that Abraham exemplifies the "knight of faith" who takes a leapt into the absurdity of faith in God, which transcends the rationality of ethics (Kierkegaard 1843/1994, xv-xvi, 61ff.). It would seem that in this context, faith precedes ethics. There are some points that require our consideration. The fact that God's command to Abraham not only places Abraham in a dilemma, but it also troubles him tremendously, and that attempts have arisen amongst biblical commentators to reconcile such violation of ethics with faith in God, clearly indicate the kind of authoritative force ethics wields. It is as if something is not quite right in this narrative, which demands a rational explanation. One explanation would be that God transcends rational dictates of what is right and wrong. Although I do not wish to enter into a debate on the nature of God, let me just state here that if God is infinite, then perhaps God should incorporate rational ethics, rather than have a part of his divine nature antithetical to it. In other words, God includes ethics, and is not unethical. Moreover, an unethical edict is still within the category of ethics. That which is amoral is beyond ethics, and God's order to sacrifice Isaac is far from being amoral. Any endorsement of assumed to be authentic command of God to execute an egregiously evil act is indeed dangerous. Not only would this endorsement be inconsistent with the claim of God's goodness and compassion, it would also be vulnerable to challenges to its object's assumed authenticity. I maintain that divine commands should not transgress the principles of moral reason.

For Kant, ideas conceived and deliberated upon by speculative reason are so far removed from verification by sense intuition that he labels them as residing within the purview of the transcendental dialectic (Kant 1787/1991, 208-212). ${ }^{9}$ His philosophical enterprise prides itself in faithfully maintaining a critical attitude in inquiry and practice. The critical attitude strives to steer away from the unhelpful stances of dogmatism, excessive scepticism, and indifferentism (Kant 1787/1991, 1-3). Indifference to metaphysical matters forfeits the opportunity to constructively grapple with ideas that Kant says would be difficult to ignore. Radical or absolute scepticism would ill-serve the intentions of contributing positively to human wellbeing, development, and social solidarity because it dampens confidence and trust in oneself and in the other. Moreover, this type of scepticism is self-refuting (see Huemer 2001, 27). 
Since matters pertaining to God, free will, and immortality of the soul, are so far removed from verification, there is no justification for adopting the dogmatic stance. The ideal attitude would be the critical approach to religious (which is largely metaphysical) matters. Such a critical posture safeguards us against any religious hegemony enacted via, for instance, unjustified inclusions of confessional doctrines in state policies and laws. Discourse that revolves around metaphysical matters may not be susceptible of empirical and mathematical proofs, but a high premium is placed upon them. These beliefs define us as who we are; as beings who are not reducible to the mechanical determinations of nature. Kant is fully aware of the significance of the discourse of metaphysics, both in its intellectual capacity as well as its relevance for practical life. An interesting feature of his approach to religion is his attempt to purify religion of revealed decrees that are largely contextual and devoid of universal consensus tied to moral reason (Kant 1798/1979, 61). However, despite the possibility of reducing Kantian religion to ethics, Kant does recognise ethics' need for works of grace, miracles, mysteries, and means of grace (Kant 1793/1960, 47-49). ${ }^{10} \mathrm{He}$ says that these elements fill a lack within ethics, and considering that they come under the purview of metaphysics, Kant relegates them to the fringes of his religion that is confined within the bounds of reason. They form what Kant labels as parerga or the frames, which enhance the work of art (Kant 1790/2000, 76). ${ }^{11}$ Religion supplements ethics through infusing final meaning in, encouraging, inspiring, and even mysteriously assisting through grace, people's adherence to the moral law. These frames or borders are not inside the realm of possible verification through theoretical reason; rather, they reside in the province of transcendent metaphysics and are accessed through speculative reason. The religious parerga fills a lack in ethics but at the same time they have the potential to infect religion with fanaticism, illusion, and superstition. Hence, they have to be tempered by reflective or critical faith - faith that adopts a critical selfchecking practice and is aware of the justifiable conditions of cognition (Kant $1793 / 1960,48) .^{12}$

It is this critical posture towards religion which aligns Kant's conception of faith with Clifford's insistence that religious beliefs must welcome opposing views and be open to re-examination. In light of the above discussion with regard to the inconsistencies between some attributes of divinity and any supposedly evil commands of God, and Kant's dialectical nature of religious beliefs, aside from viewing Clifford's principle as exacting a critical posture towards religion, it is also reasonable to interpret this principle as a cautioning procedure whereby religious beliefs that have a high probability of expressing themselves in saliently immoral actions should be considered as wanting in justifiable evidence. 
Permit me to introduce a case that I reckon will stimulate questions to think about; questions that revolve around the "ethics of belief" and "beliefs with ethics." This case is retold by Emmett Barcalow, but there is no reference source for it (Barcalow 2001, 287). However, even if the story is fictional it can still serve as a useful instrument for our reflection. Several decades ago, a society residing in a Polynesian island practiced parricide-when parents are still relatively healthy and just before they begin their descent into decrepitude, their children are morally obligated to kill them. As appalling as this practice sounds, in order to have some idea as to why this is done we need to understand the belief that engenders this practice. People in this community believe that when you die you spend eternity in the condition you were in before you died. If you were blind before you died you will be forever blind in the afterlife. Hence, while your parents are still able-bodied it would be considerate of you to kill them. Some questions to think about:

- I call this belief religious because it concerns the afterlife. These belief and practice cannot principally be placed under the category of ethics by arguing that this community is actually fulfilling its moral responsibility of ensuring the eternal happiness of its deceased members. Thinking along this line provides a dangerous justification for mass suicides, suicide bombings, heretic-torturings, and witchburnings; one that is anchored in the "moral" intention of attaining for oneself and/or others eternal salvation and happiness in the next life. There is no ethical support for sacrificing existing human life or wellbeing, for an assumed wellbeing in the afterlife. Indeed, the above belief and practice are religious rather than ethical in character. If this belief and its concomitant practice of parricide are inbuilt within the fabric of that society whereby they are handed down from generation to generation via the socialisation process, and anyone who raises doubts about them will be quickly punished, do you think it would be easy for this community to even assess the moral rationality of these belief and practice?

- Keep in mind that sons and daughters would be killing their parents out of obligation, but more so, out of love. And, most importantly, the children will not be doing it against the will of their "victims". In fact, very likely, their parents would willingly submit to this killing because the prospect of spending eternity in poor physical condition is terrifying. As an outsider, should we adopt the position of a moral relativist and be tolerant and understanding of these belief and practice? Moreover, what happens if the shaman or religious specialist claims that this belief originates from a revelation received by a revered shaman in time past who had contacted the spirits of his 
deceased fellow community members who told him that they were glad that they could spend eternity in a healthy state of body and mind; can we regard this revelation as evidence? By what means would you convince this community that in the afterlife the deceased will not spend eternity in the physical condition he or she was in close to death?

I admit that there are no easy answers to the above questions. Nevertheless, it appears that some serious violation of ethics is happening on a regular basis in this Polynesian community. This case illustrates the relevance of the evidentialist principle in our adoption of and commitment to our revered beliefs. Perhaps, if a crucial adjustment to the community's collective belief in the afterlife were made, then the practice of parricide might be viewed as immoral and its abolishment deemed necessary.

\section{Solidarity}

I think that one of the necessary requirements for forging healthy integration amongst peoples of diverse faiths and fundamental orientations is to keep the lines of conversation open. And to do this ethics must precede religious beliefs. Not only do our intimately held beliefs require submission to the moral obligation of the evidentialist principle, they also need to be firmly grounded in moral reason. Considering the relatively greater epistemic security of propositions in ethics founded on principles of sound reasoning, as compared with the propositions of religious doctrines, ethics then is more amenable towards constituting a shared bond and responsibility amongst members of a religiously plural society.

The ability to engage in inter-religious dialogue with an open mind and heart is an essential step towards fostering transformative relationships among the adherents of different faiths in a country. Although some knowledge of the systems of beliefs and practices of religions cannot be neglected, of greater importance would be the enlightened knowledge of the nature of religion in general. The diverse discourses on meta-religion will help the members of a plural society to understand religion as a human phenomenon and especially the structural makeup of religion with its different epistemic statuses for beliefs and practices. Unravelling the conditions for epistemic justification for religious statements is indispensable in the interface of religion and politics. For Georg W. F. Hegel, the concept of the state being embedded within the category of objective spirit, by necessity, subjects the state to rational principles of organisation, which have relevance in the objective realm (Hegel 1971, 1830, $20-22) .{ }^{13}$ These rational principles reflect pragmatic concerns, especially in 
matters of ethics - of rights, duties, and justice. Undoubtedly, most revealed truths may coincide with rational-moral precepts. However, in the event of a tussle between revelation and reason, justifications of political decisions, actions, measures, policies, and so forth ought only to appeal to reason. States where revealed truths are interpreted by religious authorities are not impervious to several points of contention, namely, method of authenticating the authority figure, verification of the veracity of the revelations, and the accuracy of their interpretations. Moreover, non-believers may not assent to the revelations of a particular religious tradition provided these doctrines can be incorporated into their personal worldviews. Reason supersedes revelation, not just in praxis, but also when it comes to forming a common meeting space wherein enriching dialogues can take place. Dogmatic adherence to specific doctrines strictly sourced to information said to be derived through revelation alone is, I think, inimical to inter-religious dialogue. It is reason that serves as a shared language enabling people from diverse faith backgrounds to converse with one another.

Kant's confinement of religion within the boundaries of moral reason anticipates Hegel's caution against allowing religion an influential role in state administration (Hegel 1821/1967, 165-168). The Kantian critical attitude, which avoids the extremes of dogmatism and scepticism, contributes to the delineation of the limits of possible knowledge. When it comes to examining the relation between religion and political organisation, the critical attitude operates by dividing between the sphere of objective and universally binding principles of state rule, and the sphere of the devotional and subjective enterprise of religion.

The nature of religious truths being relegated to the Kantian domain of speculative reason subverts any religious tradition's claim to superiority. I would also add that the critical attitude operates to exclude any imposition of religious doctrines on political matters that can clearly threaten the harmonious integration of the various confessional groups within a state. On account of the doctrinal principles' inherent metaphysicality, it would be difficult to countenance any proposed justification of admitting such doctrines into politics on the grounds of a democratic appeal. Permitting religious doctrines that cannot stand up to the test of moral reason to influence political governance simply because of agreement by the majority, places the political integrity of the state at risk through the likelihood of discrimination against minority groups. Moreover, an understanding of the meaning of faith and its distinction from opinion and knowledge, clarifies our perception and appreciation of each religious tradition's efforts at articulating that which is regarded as spiritual. Discourses on faith rely largely upon the method of dialectics rather than the strictly deductive method of logic and that of empirical inference in science. Faith discourses revolve around the elements of revelation, reason, scriptural interpretation, authoritative succession, and principles of organisation for a social institution. They generally 
attempt to strive for coherence of discourse, either within each of the above categories or intersections of more than one of those categories. There is in this type of discourse an opportunity for a genuine acknowledgement of the diversity of the various faiths because of their distinct historical trajectories with their correspondingly unique beliefs and practices, and at the same time, an opportunity to keep open a critical eye towards any claim of knowledge of absolute truths. ${ }^{14}$ The realisation of the open-endedness of dialectical discourses in religion can be a means to carve pathways for meaningful conversations amongst people of different faiths (including those whose faith is apathetic or opposed to religion), as well as encourage a sincere willingness to learn from and be transformed by the other's beliefs. This is a situation that far exceeds one in which people of different faiths merely tolerate one another.

\section{Conclusion}

Clifford's evidentialist principle is worth applying to religious beliefs, despite its difficulties. Our beliefs inform our actions. If our religious beliefs play a key role in the generation of actions with moral significance, then we are morally responsible for ensuring, as best as possible, the marshalling of adequate evidence for our adoption of and commitment to particular religious beliefs. In attempting to make a case for the thesis that ethics precedes religious beliefs, I resort to an application of the evidentialist principle, which dictates that maintaining a critical attitude towards adopted religious beliefs honours the evidentialist principle, whereas adopting religious beliefs perceived as highly relevant in moral practical life and which violates moral reason infringes this principle. When it comes to the translation of religious beliefs to concrete actions, the precepts of ethics must serve as the sovereign authoritative point of reference. Finally, I argue that it is within a context where ethics precedes religious beliefs and where secularity governs a state, which best fosters social solidarity amongst members of a plural society. ${ }^{15}$

\section{Notes}

1. See, for instance, Nishi Shah's "A New Argument for Evidentialism" (Shah 2006) in which the author argues that the norm of truth-seeking is part and parcel of the concept of belief, irrespective of the believer's practical intentions for believing a proposition. Neil Sinhababu accepts evidentialism, but denies that the norm of truth-seeking is necessary and sufficient for the concept of belief, and thereby rejects Shah's position (Sinhababu 2013, 155). From another viewpoint, Kevin McCain $(2014,1-2)$ states that evidentialism concerns epistemic justification; which implies that outside of evidentialism, one can have practical justification for believing something. For instance, while a person, informed of the gravity of his illness, may not have epistemic justification to believe that he will recover, he may 
have practical justification to believe so because he feels that having a positive attitude may help him cope with the disease. Furthermore, McCain echoes the understanding of evidentialism by Feldman and Conee (1985, 15), i.e., evidentialism concerns the epistemic justification for one's doxastic attitude to a proposition $p$ - either to believe $p$, not to belief $p$, or withhold judgment on $p$.

2. Here, "faith" refers to beliefs that cover metaphysical propositions not amenable to conclusive proofs via direct physical observation or mathematical deductions.

3. Schopenhauer, commonly assumed to be a pessimist, speaks about religion serving a function to the masses by providing comfort in times of suffering.

4. William Alston's (1991/1993) Perceiving God: The Epistemology of Religious Experience explores the means by which direct experiences of God can count as valid grounds for having certain religious beliefs. In his The Elusive God: Reorienting Religious Epistemology, Paul Moser (2008) speaks about religious epistemology from the perspective of "authoritative evidence" that springs from a voluntary and morally transformative human-divine relationship. While Moser's view about authoritative evidence for God's existence, as anchored in one's awakened conscience and transformed life, is open to criticism, his placement of ethics in a vital position in his epistemological system does not conflict with my paper's main thesis.

5. I do not think it necessary here for me to sketch out a case favouring moral objectivism over subjectivism and relativism.

6. Allen Wood raises this pertinent question (Wood 2008, 15).

7. For an informative discussion on the issue of whether ethics depends on the existence of God see Garcia and King (2009).

8. It may be the case that one should interpret this story purely allegorically, with its focus centred on loving and trusting God, and not on the highly questionable morality of God's demand of Abraham.

9. The fascinating thing about Kant's view of dialectic is that, while it is a method of reasoning that employs conceptions way beyond empirical justification, this form of reasoning is unavoidable (6). Kant describes the transcendental dialectic as the "logic of illusory appearance" (208-209). We are predisposed to inquire into matters that exceed the boundaries of possible experience: matters that touch upon the existence of God, the immortality of the soul, the possibility of free will and morality, and the infinitude or finitude of the universe. The purpose of Kant's searching investigation into the transcendental dialectic is to unravel this susceptibility to illusion and delineate the parameters of sound thinking thereby mitigating this illusion by cautioning the dialectician against making dogmatic pronouncements.

10. "Works of grace" refer to internal mystical experiences, "miracles" to external supernatural events, "mysteries" to special insights into supernatural realities, and "means of grace" to accessing abilities in performing miracles.

11. Kant devotes a short paragraph to this concept that is part of his elaboration on the judgment of beauty.

12. For instance, we may reasonably propose that grace is required to supplement our natural self-effort to be moral, but we cannot claim to be able to identify and divide between grace and nature, nor claim to have access to methods that necessarily activate the operation of grace (162). 
13. In Hegelian philosophy, objective spirit represents the category of the absolute (or universal reason) moving out of itself into the historical and socio-political realm (see also Inwood 1992, s.v. "spirit," 275).

14. Richard Kearney (2010, xiv) encapsulates this point most trenchantly when he says: "If divinity is unknowable, humanity must imagine it in many ways. The absolute requires pluralism to avoid absolutism."

15. I am grateful to the reviewers of this paper for their helpful comments and suggestions.

\section{References}

Alston, W. P. 1991/1993. Perceiving God: The epistemology of religious experience. Ithaca: Cornell University Press.

Aristotle. 1976, 4th cent. BCE. The ethics of Aristotle: the Nicomachean ethics, trans. Thomson, J. A. K.. London: Penguin Books.

Atran, S. 2006. The moral logic and growth of suicide terrorism. The Washington Quarterly 29(2): 127-147.

Barcalow, E. 2001. Open questions: An introduction to philosophy, 3rd ed. Belmont, CA: Wadsworth.

Clifford, W. K. 1879/1877. The ethics of belief. In Lectures and essays, vol. 2, eds. Stephen, L. and F. Pollock, F., 177-211. London: Macmillan and Co.

Feldman, R. and Conee, E. 1985. Evidentialism. Philosophical Studies (Minneapolis) 48(1): 15-34.

Garcia, R. K. and King, N. L., eds. (2009). Is goodness without God good enough? A debate on faith, secularism, and ethics. Lanham, Maryland: Rowman \& Littlefield Publishers.

Hegel, G. W. F. 1821/1967. Philosophy of right, trans. Knox, T. M. Oxford: Oxford University Press.

1830/1971. Philosophy of mind: Part III of the encyclopaedia of the philosophical sciences, trans. Wallace, W. Oxford: Clarendon Press.

Huemer, M. 2001. Skepticism and the veil of perception. Lanham, Maryland: The Rowman \& Littlefield.

Inwood, M. 1992. A Hegel dictionary. Oxford: Blackwell Publishers.

James, W. 1897/1912. The will to believe and other essays in popular philosophy. New York: Longmans, Green, and Co.

Kant, I. 1787/1991. Critique of pure reason, 2nd ed., trans. Meiklejohn, J. M. D. London: J. M. Dent and Sons. 1790/2000. The critique of judgment, trans. Bernard, J. H. Amherst: Prometheus Books. .1793/1960. Religion within the limits of reason alone, trans. Green, T. M. and Hudson, H. H. New York: Harper Torchbooks. 1798/1979. The conflict of the faculties, trans. Gregor, M. J. New York: Abaris Books

. 1817/1978. Lectures on philosophical theology, trans. Wood, A. and Clark, G. Ithaca: Cornell University Press.

Kearney. R. 2010. Anatheism: Returning to God after God. New York: Columbia University Press. 
Kierkegaard, S. 1843/1994. Fear and trembling: The book of Adler, trans. Lowrie, W. London: Everyman's Library.

Kurtz, P. 2001. Skepticism and humanism: The new paradigm. New Brunswick, NJ: Transaction Publishers.

Kurtz, P. and Craig, W. L. 2009. The Kurtz/Craig debate: Is goodness without God good enough? In Is goodness without God good enough? A debate on faith, secularism, and ethics, eds. Garcia, R. K. and King, N. L., 25-46. Lanham, Maryland: Rowman \& Littlefield Publishers.

McCain, K. 2014. Evidentialism and epistemic justification. New York: Routledge.

Mittag, D. n. d. Evidentialism. Internet encyclopaedia of philosophy. Retrieved from http://www.iep.utm.edu/evidenti/ on 3 July 2014.

Moser, P. K. 2008. The elusive God: Reorienting religious epistemology. Cambridge: Cambridge University Press.

Myers, P. Z. 2013. The happy atheist. New York: Random House.

Pascal, B. 1910. Thoughts, letters, and minor works, trans. Trotter, W. F., Booth, M. L. and Wight, O. W. New York: PF Collier and Son.

Putnam, R. D. and Campbell, D. E. 2010. American grace: How religion unites and divides us. New York: Simon \& Schuster.

Schopenhauer, A. 1851/1897. Essays of Schopenhauer, trans. Dircks, R. London: Walter Scott Publishing Co.

Shah, N. 2006. A new argument for evidentialism. The Philosophical Quarterly 56(225): 481-498.

Singer, P., ed. 1991/1993. A companion to ethics. Oxford: Blackwell Publishers.

Sinhababu. N. 2013. Distinguishing belief and imagination. Pacific Philosophical Quarterly 94: 152-165.

Wood, A. 2008. The duty to believe according to the evidence. International Journal for Philosophy of Religion 63(1): 7-24, DOI: 10.1007/s11153-007-9140-y. 